\title{
DEPOPULATION IN RURAL AREAS IN POLAND - SOCIO-ECONOMIC LOCAL PERSPECTIVE
}

\author{
Agnieszka Wojewódzka-Wiewiórska \\ Warsaw University of Life Sciences - SGGW, Poland \\ agnieszka_wojewodzka@sggw.pl
}

\begin{abstract}
The article deals with the issue of rural population decline in Poland in 1995-2017. The aim of the study was to present the phenomenon of depopulation involving a decrease in the number of people living in rural areas in Poland at the local level. Based on the literature, the potential effects of depopulation on local development were indicated. The data of the Central Statistical Office and the results of own research carried out in three rural communes in 2019 were used. The occurrence of regional differentiation of rural depopulation processes in Poland was found. Analyzing the phenomenon at the local level, it was found that as much as $38.6 \%$ of rural communes were characterized by depopulation (a loss of over $5 \%$ of the population), including for $10.7 \%$ of communes, the population decline in the analyzed period was more than $15 \%$. These areas can be considered as problem areas. A particularly unfavorable situation occurs in eastern Poland and the Opolskie Voivodeship. There was a positive correlation between the loss of population and the development of own revenues of communes' budgets. Studies show that the phenomenon of depopulation is mainly caused by a negative natural increase, which was preceded by a migration outflow associated with the lack of jobs in rural areas.
\end{abstract}

Key words: depopulation, rural areas, population, problem areas.

\section{Introduction}

In recent years, the population has been decreasing in Poland and according to data for 2017 is 38.4 million people (CSO, 2019), which is $99.5 \%$ compared to the population in 1995. On a general scale, the population in cities decreases slightly, and increases in the countryside. The phenomenon of population shrinkage, including the outflow of rural population, also occurs in other countries (Cena \& Fernandez-Cavada, 1986; Johnson \& Lichter, 2019; Kotowska \& Jóźwiak, 2003; Kuczabski \& Michalski, 2013; Li, 2015; Shrinking... 2017). The course and intensity of population outflow processes from rural areas in Poland varies over time and in space (Bański, 2005 , 2008). The outflow of people is caused by unfavorable economic processes or low competitiveness of the area in relation to other areas to which the population migrates. Looking historically at the shaping of the rural population (Eberhardt, 1994), it can be stated that in the period after the Second World War there was a significant population outflow in rural areas, which was compensated by a high birth rate (Bański, 2008; Gawryszewski \& Potrykowska, 1988). In 1946, there were 15.6 million people living in the rural areas, i.e. $66 \%$ of the population of the country (Bański, 2008). In 2003, the rural areas were inhabited by 14.7 million people, that is only $38.4 \%$ of the total population, while in 2017 there were 15.3 million people living in the villages $(39.9 \%$ of the total population) (CSO, 2019). Currently in rural areas in the face of a weakening birth rate (in 2015 it was negative at -0.1 , migration processes play an increasingly important role in spatial diversity of the population (Eberhardt, 1994). Locally, it depends on individual features and functions of rural areas, largely location and communication with cities and is the result of changes in the economy, i.e. system transformation in Poland after 1989 and access to new labor markets after Poland's accession to the EU in 2004. In the majority of rural areas, the cumulative problems mainly of economic nature (especially, low profitability of work in agriculture, unavailability of non-agricultural jobs, high unemployment) push rural population to cities ( $\mathrm{Li}, 2015)$. The population growth is characterized by rural areas located around large cities (Biegańska \& Szymańska, 2013), thanks to which there is a positive migration balance in the countryside (Bański, 2005) identified for the first time at the beginning of the $20^{\text {th }}$ century.

In the literature on the subject, two types of depopulation are usually distinguished: the traditional type of depopulation in the area where the main reason for depopulation is migration outflow (negative migration balance) and so-called a new type that is caused primarily by natural losses (negative natural growth). It can be concluded that the new type is a consequence of long-term traditional depopulation (Bucher \& Mai, 2005; Celińska-Janowicz et al., 2010). The term depopulation is understood as the process of depopulation of a certain area, i.e. the population decreases (Szukalski, 2015). Based on previous research (Eberhardt, 1989; Strzelecki, 1995), ), it was assumed that areas where depopulation occurs are characterized by a population loss of more than $5 \%$ over a longer time horizon, areas with a population decline of more than $15 \%$ were identified as those with extreme depopulation.

The literature indicates that the identified problem of population loss is the basis for the identification of population problem areas or areas with demographic depression (Bański, 2002; Śleszyński et al., 2017; Zagożdzon, 1998). Depopulation and unfavorable 
demographic changes are also connected with the features of the peripheral regions (Penzes, Pasztor, \& Tatrai, 2015). In the scientific work on depopulation, the authors most often focus on the diagnosis of changes in the population. An innovative approach is to show the process from the point of view of the authorities of a specific territorial unit (local level) and to show the relationship between changes in the population and the amount of income in the local budget, which is an important instrument for supporting local development.

The aim of the paper was to present the phenomenon of depopulation in the rural areas in Poland at the local level. To reach the purpose, the following tasks have been set: 1) to indicate the potential socio-economic effects of depopulation for local development; 2) to determine the intensity of the rural population decline at the regional and local level; 3) to indicate the determinants and effects of population loss in rural communes, especially the impact on communal budgets.

\section{Materials and Methods}

The research process took place in successive stages. Based on the analysis of the literature on the subject, the potential socio-economic effects of local development were identified. In the next step, using the data from the Central Statistical Office (CSO, 2019), changes in the number of population in rural areas were determined at the regional (voivodship) and local level (rural communes) ${ }^{1}$. Relations between changes in population, migration balance, natural increase and the amount of own revenues of communes were indicated. Then in 2019, in-depth research was conducted in deliberately selected 3 rural communes (computer assisted telephone interview with employees of commune offices), in which the largest outflow of population in the years 1995-2017 was found. The research period covers the years $1995-$ 2019 , which is related to the availability of population data in public statistics. Data analysis was based on the linear regression method. The results were presented using maps, tables and graphs created using the MapInfo and Statistica software.

\section{Results and Discussion \\ Depopulation at the regional level}

In 1995-2017, the decrease in the number of people was found in 6 Polish regions out of 16 existing ones (Figure 1). The largest population loss occurred in the Podlaskie and Opolskie voivodships, and was respectively $11.4 \%$ and $10.1 \%$. The Eastern Poland is a densely depopulated area, which confirms the results obtained earlier by other authors (Bański, 2008). This may result from the specific location of the regions making up Eastern Poland at the external EU border and the fact that they are included in the peripheral and underdeveloped regions. In other regions there was an increase in the number of people living in the countryside, which was the highest in Pomorskie (125.4\%), Wielkopolskie (112.3\%) and Małopolskie (111.7\%) voivodships. The number and importance of cities located in the region (Śleszyński et al., 2017), to which the rural population migrates in search of better

$\begin{array}{ll}\square & 111-125.4 \\ 105-111 & (3) \\ \square & 100-105 \\ \square & 95-100 \\ \square & \text { (3) }\end{array}$

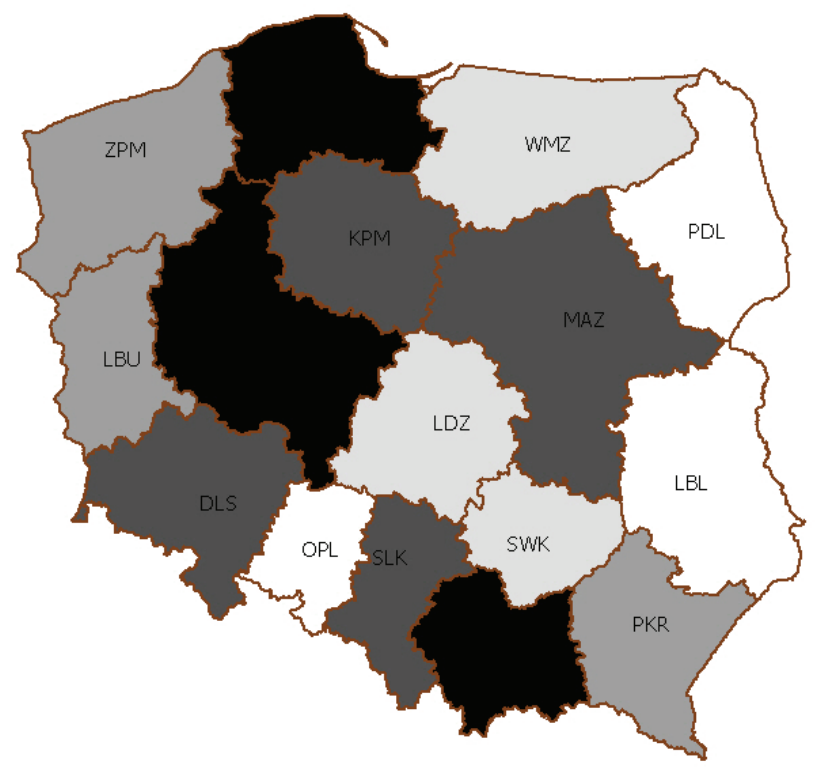

Figure 1. Changes in the number of rural population in Polish regions in 1995-2017 (\%).

Source: compiled by the author based on CSO (2019) data.

\footnotetext{
In Poland, there are (as of 2017): voivodships (16), counties (314) and communes (2478); there are 3 types of communes: rural (1555), urban (302), urban-rural (621).
} 

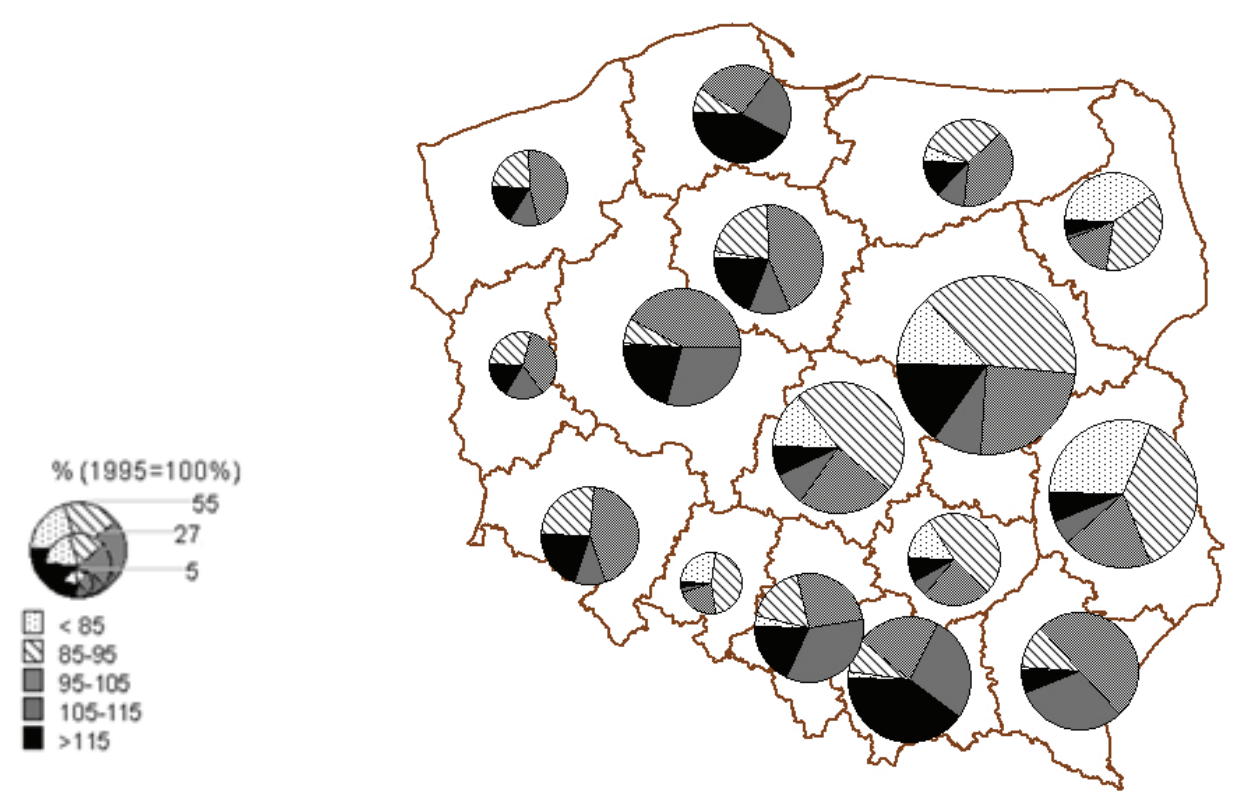

Figure 2. The structure of rural communes in Polish regions according to changes in the population in 1995-2017.

Source: compiled by the author based on CSO (2019) data.

living conditions, is of great importance in explaining the existing differences between regions.

Individual regions were internally differentiated in terms of population outflow from rural areas, which can be observed by analyzing population changes in 1995-2017 at the local level (communes) (Figure 2). In Poland, as much as $38.6 \%$ of rural communes were characterized by depopulation (a loss of over $5 \%$ of the population), of which $10.7 \%$ were rural areas with a loss of more than $15 \%$. Communes in which the depopulation process was found out predominantly prevailed in the regions such as Podlaskie, Opolskie, Lubelskie, Świętokrzyskie and Łódzkie. Particularly worrying is the high percentage of communes where the population reduction was greater than $15 \%$. This applies to the following voivodships: Podlaskie, Opolskie and Lubelskie, in which these communes accounted for $41 \%, 31 \%$ and $28 \%$ respectively. These areas can be considered as problem areas (Zagożdzon, 1998), where the disadvantageous phenomenon of a large population loss causes internal anomalies and requires external help (Szlachta, 1984). The most favorable situation was in the following voivodships: Małopolskie, Pomorskie and Śląskie, where rural communes characterized by an increase in the number of population were predominant.

\section{The effects of depopulation at the local level}

Previous studies show the existence of many adverse effects of population outflow in various spheres associated with local development. These include, among others: changes in the structure of the population by age and gender (Stasiak, 1992); changes of the family and local communities (including the impediment of caring and care functions towards weaker members of the family, including the elderly)) (Stockdale, 2002; Szukalski, 2015); changes in the economic structure of the population; lowering resources on the labor market, weakening entrepreneurship and innovation (Celińska-Janowicz et al., 2010); deformation of the local market of goods and services; problems in the real estate market (a drop in their prices due to low demand and inheritance)); decrease in anthropopressure (Szukalski, 2015); inefficiency of the local public finances system; increased costs of infrastructure maintenance ( $\mathrm{Li}$, 2015; Mann, 2004), especially social infrastructure. As a result, the depopulation areas are characterized by low competitiveness. It also indicates the beneficial effects of depopulation, ie an increase in the safety of life (Szukalski, 2015) and the opportunity to improve the functioning of agriculture through the enlargement of farms (Bański, 2002).

To determine the consequences of changes in the population for local development, the amount of own income of rural communes, which mainly includes local taxes, was used. In reference to the various types of depopulation in the literature (Bucher \& Mai, 2005), the natural increase and the migration balance were used. In order to estimate the impact of individual variables on the development of own revenues of rural communes, a linear regression analysis was applied (Figure 3 and 4). Based on the first of the estimated models (Figure 3), a positive relationship can be found between the analyzed variables $(\mathrm{r}=0.3853)$. This means that if the natural increase increased by a unit, the income increased by PLN 161.2 thousand. 


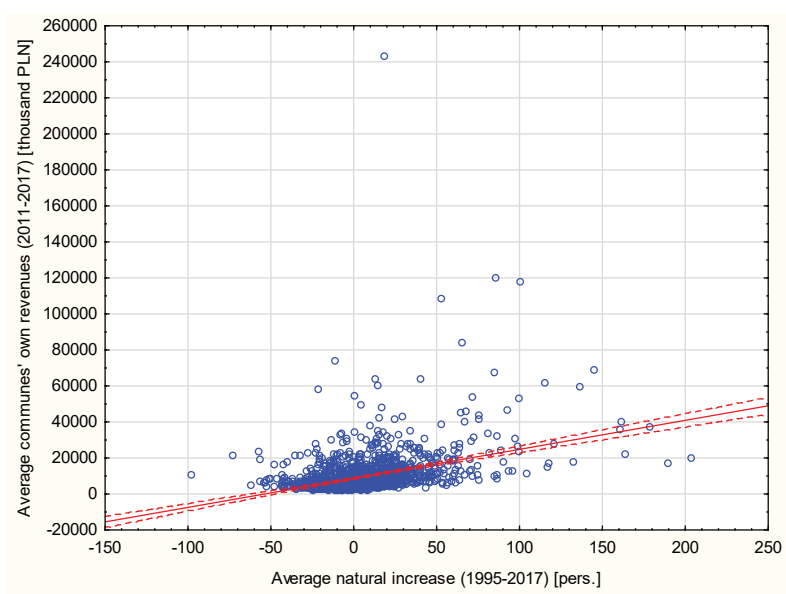

Figure 3. Natural increase and changes in own revenues of rural communes in Poland. Source: compiled by the author based on CSO (2019) data.

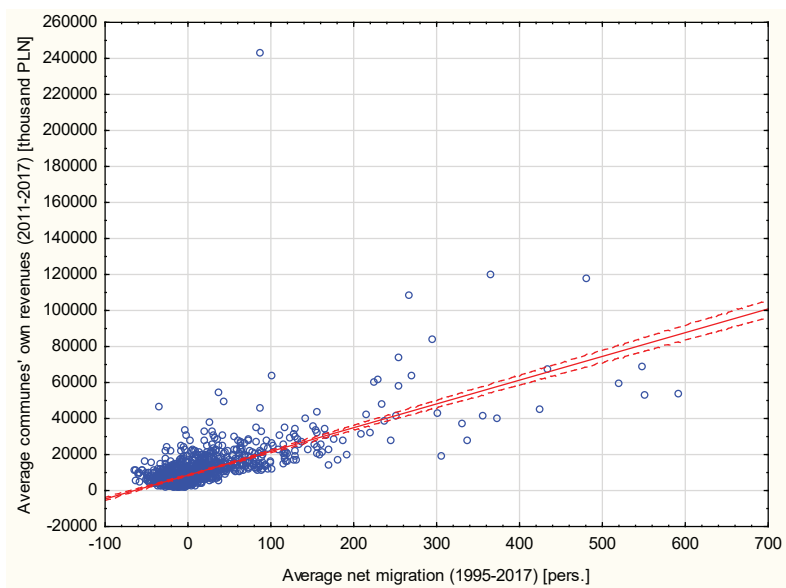

Figure 4. Migration and changes in own revenues of rural communes in Poland.

Source: compiled by the author based on CSO (2019) data.

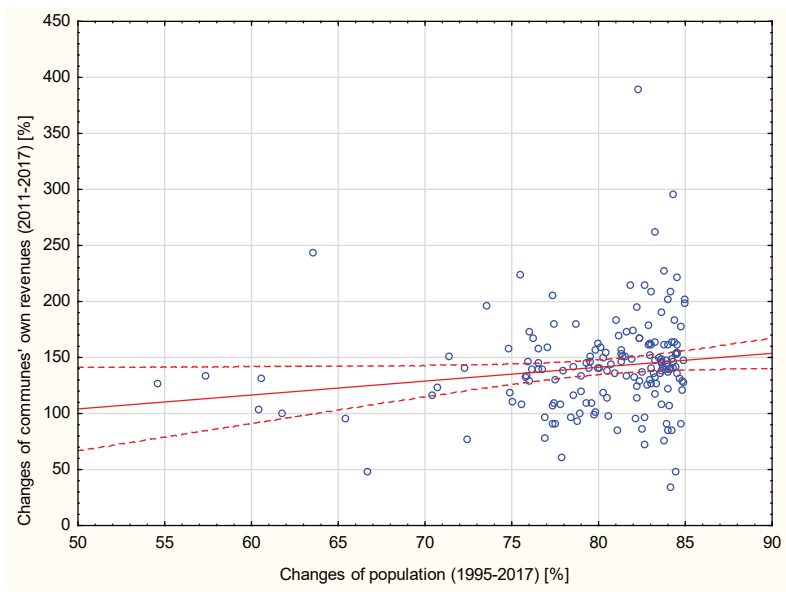

Figure 5. Change in the number of population and change in the amount of own revenues of rural communes in Poland characterized by extreme depopulation.

Source: compiled by the author based on CSO (2019) data.

Positive dependence was also found between the migration balance in the commune (Figure 4) and the amount of own revenues of communes $(\mathrm{r}=0.6845)$. If the migration balance changed by a unit, the revenues increased by PLN 131.9 thousand. The relationships found were statistically significant.

Figure 5 shows the dispersion of communes characterized by a large loss of population (extreme 
Characteristics of analyzed rural communes affected by depopulation in 1995-2017*

Table 1

\begin{tabular}{|lcc|cc|}
\hline \multicolumn{1}{|c|}{ Specification } & Czyże & Orla & $\begin{array}{c}\text { Dubicze } \\
\text { Cerkiewne }\end{array}$ \\
\hline Population in 2017 & & 2034 & 2770 & 1567 \\
\hline Changes in the population number 2017-1995 (\%) & 61.77 & 63.61 & 65.43 \\
\hline Population density per 1 km ${ }^{2}$ & 2017 & 15 & 17 & 10 \\
& 2002 & 20 & 23 & 13 \\
\hline Average annual net migration per 1000 population & & $-2,8$ & $-1,2$ & $-2,6$ \\
2003-2017 & & -18.7 & -16.7 & -18.8 \\
\hline The average annual natural increase per 1000 population 2002-2017 & & 2.16 & 2.03 & 1.90 \\
\hline Average annual loss of population 1995-2017 (\%) & 2017 & 11.8 & 13,4 & 10,8 \\
\hline Population in the pre-productive age (\%) & 2002 & 13.4 & 13.3 & 13.5 \\
\hline Population in post-working age (\%) & 2017 & 38 & 39.8 & 40.7 \\
& 2002 & 38.9 & 40.4 & 39.6 \\
\hline Feminization rate (persons) & 2017 & 105 & 108 & 104 \\
& 2002 & 104 & 108 & 98 \\
\hline
\end{tabular}

* years depending on the availability of statistical data

depopulation), which was linked to changes in the amount of own revenues. There is a positive, relatively weak relation $(\mathrm{r}=0.1548)$ between the analyzed variables. This is due to the fact that in the group of communes in which there is a large outflow of population, the occurrence of such communes was found, which, with the same changes in the population, achieve different levels of own income. This may mean that a group of communes where depopulation occurs is heterogeneous in terms of functions performed, employment of residents, which may translate into different types and sizes of inflows that make up their own income (taxes on real estate, agriculture, forestry, transport and participation in central taxes, i.e. PIT and CIT).

Three neighboring rural communes, located in the Podlaskie voivodship, i.e. a region where the largest outflow of population in the analyzed period was recorded, was selected for in-depth studies. The general characteristics of the communes are presented in the Table 1.

All studied communes are characterized by low population density, which is decreasing year by year. One can speak of a permanent, yearly population decline, which concerns the area of the whole commune, not only selected villages. The surveyed representatives of communes pointed out that currently the population decline is caused by low natural increase, which is confirmed by data from official statistics (CSO, 2019). For a long time, older people are a large part of the community, the number of deaths is high, few children are born (about 10-20 a year). In the case of migration outflow, observed mainly in previous years, it was pointed out that young people would travel permanently in search of work to cities in the region and other large cities in Poland. Residents of the studied communes also went abroad (Germany, Belgium, Iceland), in this case the migrations were of a chain nature. The inflow of new inhabitants is rarely observed, mainly due to the poor quality of soils hindering farming in agriculture and the lack of jobs in the commune. Only in the Orla commune there are large economic entities offering jobs outside agriculture (wood panels factory, wind farms). A factor attracting new residents (1-2 people) are natural values of the area (Białowieża Forest). In the commune people who are interested in peaceful life in the countryside (Szukalski, 2015), pensioners or people for whom the new house is a second house, used for recreational purposes settle. There is also an influx of Ukrainians who choose the examined communes due to their close location and differences in the possibilities of individual development that exist between Poland and Ukraine. Taking up work remotely is difficult due to limited access to the Internet.

As consequences of depopulation the area was pointed to low tax revenues to the commune's budget, high costs of infrastructure maintenance: the commune office, health center and schools ( $\mathrm{Li}$, 2015; Mann, 2004). Municipal authorities have taken measures to adapt the infrastructure to real needs, but sometimes there is no way to change, for example, in the commune there is one school that cannot be closed. In the future, this situation may result in the necessity to incur even higher costs of infrastructure maintenance. Uninhabited homes remain in the care 
of their families or neighbors, sometimes find new buyers or, in the case of land, new tenants (Bański, 2002). There was no indication of very low prices on the local real estate market.

\section{Conclusions}

On the basis of conducted research, the following conclusions can be reached:

1. A characteristic feature of rural areas in Poland is their wide diversity in terms of changes in the population, which is visible in the intra-and inter-regional approach. On the one hand, there are areas characterized by depopulation, where, due to the loss of population, numerous adverse consequences of the socio-economic sphere may appear i.e. unfavorable population structure, deformation of the labor market, inefficiency of local public finances, problems with development and maintenance of infrastructure and significantly impede local development. This applies to as much as $38.6 \%$ of rural communes, particularly unfavorable situation in Eastern Poland and the Opolskie Voivodeship. On the other hand, there are communes located in the vicinity of large cities with very large population growth, which may also constitute a barrier to development. Maintaining such a large diversity in the long term may result in problems in socio-economic development at a level higher than the local one.

2. The positive correlation between the loss of population and the development of own revenues of communes' budgets allows us to think that in the context of local development, among many consequences of depopulation, it is precisely the reduction in budget revenues of local governments that is particularly dangerous. Decreasing revenues of communes combined with the need to incur higher budget expenses related to, among others, aging of the population, dispersion of settlements, high infrastructure maintenance costs will significantly and even more than currently limit the possibilities of financial stimulation of socio-economic development processes at the local level.

3. Qualitative research indicates that at first the population loss in the analyzed communes was caused by migration outflow related to the lack of jobs in rural areas. Over the course of time, the main cause of depopulation became a negative natural increase. This shows how important it is at local level to stimulate entrepreneurship and create new jobs outside agriculture.

\section{References}

1. Bański, J. (2002). Typy ludnościowych obszarów wiejskich (Population types of rural areas). In: Bański J., Rydz E. (eds.), Społeczne problemy wsi (Social problems of the village). Studia Obszarów Wiejskich, No. 2, PTG, IGiPZ PAN. Warszawa, pp. 41-52. (in Polish)

2. Bański, J. (2005). Przestrzenny wymiar współczesnych procesów na wsi (The spatial dimension of modern rural processes). Studia Obszarów Wiejskich, Vol. 9, IGiPZ PAN, Bernardinum, Warszawa, pp. 60-61. (in Polish)

3. Bański, J. (2008). Problemy demograficzne obszarów wiejskich (Demographic problems of rural areas). Studia i raporty IUNG - PIB, z. 12, pp. 9-18. (in Polish)

4. Biegańska, J., \& Szymańska, D. (2013). The scale and the dynamics of permanent migration in rural and peri-urban areas in Poland - some problems, In: Szymańska, D., Chodkowska-Miszczuk, J., eds., Bulletin of Geography. Socio-economic Series, No. 21, Toruń: Nicolaus Copernicus University Press, pp. 21-30. DOI: 10.2478/bog-2013-0017.

5. Bucher, H., \& Mai, R. (2005). Depopulation and its Consequences in The Regions of Europe, DG III Social cohesion. Brussels.

6. Celińska-Janowicz, D., Miszczuk, A., Płoszaj, A., \& Smętkowski, M. (2010). Aktualne problemy demograficzne regionu Polski wschodniej (Current demographic problems of the Eastern Poland region). Raporty i Analizy EUROREG 5/2010, pp. 1-65. (in Polish)

7. Cena, F., \& Fernandez-Cavada, J.L. (1986). Spain: Rural development under rapid depopulation, European Review of Agricultural Economics, 13 (3), pp. 415-432.

8. Central Statistical Office, Local Data Base, Retrieved February, 5, 2019, from http://stat.gov.pl/bdl/.

9. Eberhardt, P. (1989). Regiony wyludniajace się w Polsce (Regions depopulating in Poland). Prace Geograficzne, IGiPZ PAN, 148. (in Polish)

10. Eberhardt, P. (1994). Distribution and dynamics of rural population in Central Eastern Europe in the $20^{\text {th }}$ century, Geographia Polonica, Polish Academy of Sciences, Vol. 63, pp. 75-94.

11. Gawryszewski, A., \& Potrykowska, A. (1988). Rural depopulation areas in Poland, Geographia Polonica, Polish Academy of Sciences, Vol. 54, pp. 81-99.

12. Johnson, K.M., \& Lichter, D.T. (2019). Rural Depopulation: Growth and Decline Processes over the Past Century, Rural Sociology 84(1), pp. 3-27. DOI: 10.1111/ruso.12266. 
13. Kotowska, I.E., \& Jóźwiak, J. (eds.), (2003). Population in Central and Eastern Europe: Challenges and opportunities, Statistical Publishing Establishment, Warsaw.

14. Kuczabski, A., \& Michalski, T. (2013). The process of depopulation in the rural areas of Ukraine, Quaestiones Geographicae, 32(4), Bogucki Wydawnictwo Naukowe, Poznań, pp. 81-90, DOI: 10.2478/ quageo-2013-0035.

15. Li, X. (2015). Rural Depopulation in China: A Comparative Perspective, International and Multidisciplinary Journal of Social Sciences, 4(2), pp. 149-174. DOI: 10.17583/rimcis.2015.1503.

16. Mann, S. (2004). The Depopulation of Rural Areas and the Farming System, 94 ${ }^{\text {th }}$ EAAE Seminar 'From households to firms with independent legal status: the spectrum of institutional units in the development of European agriculture', Ashford (UK), 9-10 April 2005 Retrieved February 15, 2019, from http:// ageconsearch.umn.edu/.

17. Penzes, J., Pasztor, I.Z., \& Tatrai, P. (2015). Demographic processes of developmentally peripheral areas in Hungary, Stanovnistvo, 53(2), pp. 87-111. DOI: 10.2298/STNV1502087P.

18. Shrinking Rural Regions in Europe. (2017). ESPON.

19. Stasiak, A. (1992). Problems of depopulation of rural areas in Poland after 1950, Landscape and Urban Planning, Vol. 22, Issues 2-4, pp. 161-175. DOI: 10.1016/0169-2046(92)90020-Z.

20. Stockdale, A. (2002). Out-Migration from Rural Scotland: The Importance of Family and Social Networks, Sociologia Ruralis, Vol. 42, No. 1, pp. 41-64.

21. Strzelecki, Z. (1995). Założenia i zasady polityki regionalnej (Assumptions and principles of regional policy). in: Polityka regionalna w rozwoju obszarów wiejskich, Materiały z ogólnokrajowej konferencji, SGGW, Warszawa, pp. 45-60. (in Polish)

22. Szlachta, J. (1984). Wschodnie tereny przygraniczne jako obszar problemowy (Eastern border areas as a problem area). Gosp. Plan., 12, pp. 552-559, Warszawa. (in Polish)

23. Szukalski, P. (2015). Demograficzno-społeczne konsekwencje depopulacji w województwie łódzkim (Sociodemographic consequences of depopulation in the Lodz region). Problemy społeczne, Polityka społeczna w regionie łódzkim, Regionalne Centrum Polityki Społecznej w Łodzi, Łódź, pp. 3-20. (in Polish)

24. Śleszyński, P., Bański, J., Degórski, M., \& Komornicki, T. (2017). Delimitation of problem areas in Poland, Geographia Polonica, Vol. 90, Issue 2, pp. 1-8. DOI: 10.7163/GPol.0088.

25. Zagożdżon, A. (1988). Kilka uwag o obszarach problemowych (A few notes about problem areas). In: Gospodarka przestrzenna, region, lokalność, Biuletyn KPZK, 138, pp. 137-147. (in Polish) 